\title{
Those Who Pause to Listen
}

Michelle Izmaylov, MD

Neurology ${ }^{\circledR}$ 2022;98:120-121. doi:10.1212/WNL.0000000000013052

Her words are difficult to comprehend, but it seems she is searching for answers-

Nordmenns corona bae... Tuesday Tuesday when ... jimjam brain ... I'm okay ... machinative papsidiction I kind of feel unresolved.

And with this implied question she gazes up, a woman with butterscotch-gold hair threaded through with faint traces of gray. Her chart speaks of postoperative moderate to severe receptive and expressive aphasia with alexia and agraphia following a left frontoparietal craniotomy 5 months ago for treatment of a large meningioma that involved the anterior left temporal lobe with significant mass effect with severe left-toright subfalcine shift and possible early uncal herniation, and of how she has now been readmitted with concern for headaches. Her nurses speak of her intermittent and seemingly random agitation, the unexpected frantic flailing of arms and writhing in bed and a blanket flung across the room, especially when they struggle to understand her speech and sometimes try to hurry to escape another awkward attempt at conversation. Her husband speaks of making sure she's on the track to getting better before she's discharged; he spends his evenings with furrowed eyebrows at her bedside, nodding as she speaks but admitting later that he struggles to understand much of anything she tries to tell him. The patient speaks of cookie jars and kittens, her earnest eyes pleading for anyone to listen for intelligible scraps of meaning.

Behind me, a loud clock in the hallway outside ticks down the seconds I've spent with her this morning. I've fallen behind on rounds, and noon huddle with my team is fast approaching. But I know everyone who stands at her bedside will hear the relentless reminder of that clock to mind the schedule. Standing beside her, I ask: "Did the neurosurgeons come to update you on the brain MRI?"

She shakes her head. The patient pins me under her gaze, her eyes dark with a familiar echo of panic I have often observed in those bracing for bad news. Her hand quests out; she grasps my sleeve. Nettstedeten, she says. What happened ovenfor?! Among the tangled words, there is no mistaking the worry and insistence in her voice.

I listen to the restless ticking. I think about the other patients waiting for me to see them. I close the door to the hallway, silencing the clock, knowing the other patients waiting will appreciate this same respect lent to them later that morning.
Correspondence

Dr. Izmaylov

michelle.l.izmaylov.1@

vumc.org

Then I pull a plastic chair up to her bedside, the scrape of its legs the only sound in the room. I sit beside her. She bites her lip. Her hands fist in the blankets. The sinus rhythm on her telemetry monitor climbs into tachycardia.

The MRI shows the meningioma came back.

The news is bad but not completely unexpected. Recent prior imaging was concerning for recurrence. But on the monitor, her heart rate spikes higher. Her jaw hinges open. Oljeprisen but supnism labrador dog dog I... She claps her hands over her eyes and kicks her legs, twisting the blanket around her body. Tomu. Molituden. Prosentis! She grabs the blanket, smothers it over her mouth for a half-second, then shakes her head and flings it aside. Alasden scountomat!

She speaks nearly no words in any language that I know, but I understand her clearly. In the wake of bad news, many patients have mouths full of cotton and eyes full of fog, and failure.

"You did everything right," I tell her. "You went to all your appointments. Sometimes these things just happen. But you did everything you could. That's why we were able to catch it so soon."

She breathes out, and her body deflates against the bed. Her arms fall limply to her sides. Lying in the sheets like the remnants of a pricked balloon, she looks up at the ceiling like the bed is a ball and chain tethered to her body and the world is too heavy for her to carry. And I have seen it before: the patients whose lives have become a sequence of horrors, who have tried to suffocate the truth but found no blanket thick enough, where every day is another brick stacking around their bodies and threatening to bury them. Sometimes the bricks stack so high that it seems just as impossible for anyone to enter as it is for the patient to break out.

But there are ways to tell even for those who will not speak of heartache and the walls they build. Ways to try to break through.

"The neurosurgeons already know. They saw the image. They have a plan for treatment," I tell her, offering a verdant sprig to grasp on a winter morning. I wait for her to look at me. She turns her head, the shadow over her eyes dissipating. I take her hand, take some of the bricks, and give her something softer to hold. "They're going to plan another surgery. They'll come talk to you this afternoon. We'll take care of you." I squeeze 
her hand. "We're here for you. We're all a team in this together."

She opens her mouth slightly and brings a hand to her lips. Her fingers make the motion of slipping something invisible in her mouth, like a small candy, or a small hope to tuck under her tongue and carry with her. Oh ... She closes her mouth, sucking on the information. Suromlag humdelsen ... contact my husband about the guyrill?

"I will. I’ll call him right after this."

She nods. I let go, and her hand slides to the bedsheets. Her body seems a little more relaxed, some of the tension eased out of her shoulders. But I notice the shiver in her hands resting on the blankets. Cold mornings are not easily shrugged off, and there is no jacket warm enough to shield her from the frigidity she feels. She cannot tell me with her words of all the frost she feels. But if I watch carefully, I can notice when her feet are slipping on black ice, and my hands can catch her when she collapses before she hits the ground.

"I'll come back in the afternoon to check on you," I tell her.

Her fingertips lightly tap her thigh. She crinkles her nose, the freckles across its bridge like sprinkled cinnamon that bunch together as she thinks. Then, she lays her hand down flat and calm. Okay, she says. She closes her eyes as I stand to go, her hands resting steadily on the blankets heaped across her lap.

The hallway outside is quiet except for the ticking clock. I look up and down the closed doors of other patient rooms. Within some of these rooms are other patients who struggle to make themselves be understood, those who cannot say words because of a stroke or dementia or even a urinary tract infection that clouds their minds and jumbles their communication. And even those just receiving bad news, the patients who answer with silent stares and can't convey words around choking bubbles of panic crawling up their throats. But none of these patients have entirely lost their voices. They can all speak. People may not always be able to say with words what they think and need. But they will always show those who are careful to pay attention. There is much meaning to gestures, haptics, and paralinguistics. Those who take the time to listen will hear what must be said.

Later that day, I return to find her spooning up yogurt while her son's voice crackles through the speaker on her phone. She glances up as I close the door behind me. She says something I can't hear into the phone before she turns it off, but the words are light and have the soft quality of butterfly wings.

I ask: "How do you feel?"

She sits up straighter. Her hands resting on her lap seem tired in the way of someone who has been scrubbing the sorrow out of the floorboards of her heart all day. But she waves to me. Book book automation... She smiles, and she reaches out to hold my hand. I'll be all right.

\section{Publication History}

Received by Neurology May 14, 2021. Accepted in final form November 4, 2021. 


\title{
Neurology
}

\author{
Those Who Pause to Listen \\ Michelle Izmaylov
}

Neurology 2022;98;120-121 Published Online before print November 15, 2021

DOI 10.1212/WNL.0000000000013052

This information is current as of November 15, 2021

Updated Information \&

Services

Subspecialty Collections

Permissions \& Licensing

Reprints including high resolution figures, can be found at: http://n.neurology.org/content/98/3/120.full

This article, along with others on similar topics, appears in the following collection(s):

All Clinical Neurology

http://n.neurology.org/cgi/collection/all_clinical_neurology

All Education

http://n.neurology.org/cgi/collection/all_education

All global neurology

http://n.neurology.org/cgi/collection/all_global_neurology

Information about reproducing this article in parts (figures,tables) or in its entirety can be found online at:

http://www.neurology.org/about/about_the_journal\#permissions

Information about ordering reprints can be found online:

http://n.neurology.org/subscribers/advertise

Neurology ${ }^{\circledR}$ is the official journal of the American Academy of Neurology. Published continuously since 1951, it is now a weekly with 48 issues per year. Copyright (C 2021 American Academy of Neurology. All rights reserved. Print ISSN: 0028-3878. Online ISSN: 1526-632X.

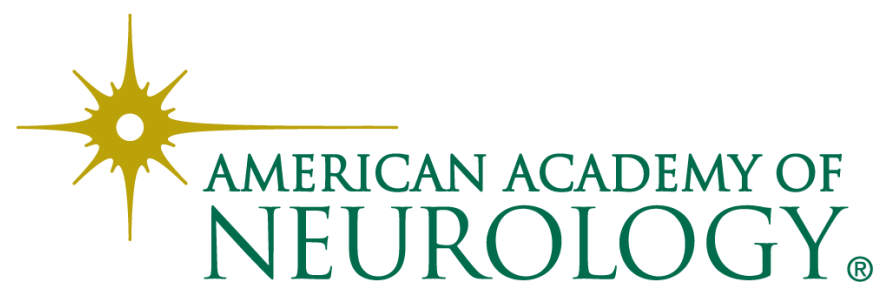

